\title{
3
}

\section{A Critical Analysis of Multiculturalism and Deviant Identities: Untold Stories of Japanese Americans without Nations}

\author{
Takumi Honda
}

\subsection{Introduction}

What part have Japanese immigrants played in multiculturalism in America? How have such immigrants been described in the prevailing multicultural discourse? In recent years, discussions of multiculturalism and Japanese immigrants are increasingly attracting more attention. In fact, Japanese immigrants are now regularly mentioned in American history textbooks as representative "good Americans." This suggests that Japanese immigrants have become an integral part of multicultural education in the US. However, the history and identity of Japanese immigrants described in these discussions and textbooks do not completely cover the stories of Japanese immigrants in America, especially those who were marginalized and forced to struggle to maintain their distinctive identities. Those aspects of Japanese immigrants depicted in the established discourse of history and identity present only one model for Japanese immigrants. When the immigrants crossed national borders, they encountered complicated struggles over their own identities. How should such a struggle be understood? What does this understanding mean to the contemporary literature of multiculturalism?

In order to address these questions, this chapter starts by focusing on how Japanese immigrants have been described in conventional discourses of American multiculturalism. Second, I will pay specific attention to people who have been heretofore barely described in the traditional history of Japanese immigrants. Third, I will examine the significant influence that conventional multiculturalism discourses have exerted on the omission of particular types of Japanese immigrants, 
with a focus on the concepts of "tolerance" and "integration." This will be followed by brief concluding remarks.

\subsection{Mainstream discourses regarding multiculturalism and Japanese immigrants in America today}

The issue of migration is, needless to say, important for understanding modern society. The global flow of people is obviously a major concern of policy makers as well as scholars of international affairs. In America, after 9/11, multiculturalism, which is deeply tied to the image of "tolerance" in the minds of Americans, is actually spurring disputes in the international community. While many of the discourses of multiculturalism straightforwardly promote tolerance and acceptance of other cultures, some argue that such discourses only result in concealing the violence that certainly continues to this day (Yoneyama, 2003, p. 223). This is also the case in the context of Japanese immigrants in the US. What has been described as the history of Japanese immigrants continues to exclude and marginalize particular identities from the legitimate history. Behind a series of such descriptions of Japanese immigrants has always been a politics habitually controlled by the majority. The repetition of such a description in classrooms and everyday conversations leads to the continuous exclusion of those do not fit the ideal immigrant figure of multicultural discourse. Multiculturalism in this sense has performed its function of absorbing Japanese Americans and other ethnic groups into the "multiculturalism" framework by establishing certain models of "good Americans," and often ended up by homogenizing them into the unified idea of patriotic citizens (Grant \& Sleeter, 2009).

In America in the latter half of the 1980s, a new concept of "diversity" began to be widely referenced, and the concept of "multiculturalism" subsequently began to be discussed intensively. The word "multiculturalism," with a concomitant concept of tolerance, was derived from America's efforts to promote a change in the majority's conventional public awareness of minorities (Inoue, 1999, p. 88). It has often been said that this type of multiculturalism was the result of identity politics primarily developed by African Americans and Asian Americans in order to protest discriminatory structures in the US (Tai, 1999, p. 38). Initially, multicultural movements strived to create a multicultural society by embracing all minority ethnic groups and cultures. However, multiculturalism is said to have begun performing the 
role of concealing the political and economic gap between minority groups and cultural diversity within a minority group (Gordon \& Newfield, 1996). Subsequently, it was often said that the discourse of multiculturalism only functions to integrate such people into the framework of the pre-given "multi-cultural," creating an impression of tolerance presumably residing in the minds of the majority. In this way, multiculturalism began to be used as a theory of national integration (Yui \& Endo, 1999). ${ }^{1}$

In the 1990s, multiculturalism became even more visible. This concept continues to be welcomed widely in the US even now. Discussion of multiculturalism is particularly active at educational institutions, higher educational institutions in particular, where ethnic groups with different roots are actively featured in classrooms as a part of the history of multicultural America. Multiculturalism is, therefore, still believed to represent an imperative and indispensable aspect of America that comprises a wide variety of cultures (Hollinger, 1995, p. 150).

The cases where Japanese immigrants are utilized by mainstream multicultural discourse in America often emphasize the collapse of their identity resulting from compulsory confinement during the Second World War, and regularly refer to the reconstruction of their identity as Japanese American with the victory of the compensation movement in the post-war period. Although textbooks feature Japanese immigrants as a part of the success of multiculturalist policies in the US, they ignore the complicated, multi-layered, and diverse experiences of Japanese immigrants. In fact, multicultural education often fails to focus on the identity of Japanese immigrants during the period from their first arrival in the US to their compulsory confinement (Petersen, 1971). In order to clarify this point, it is necessary to review the academic research previously conducted on Japanese immigrants, and compare this with the narratives of those who were marginalized and the movements continuously protesting against the established social structure.

The period from Japanese immigrants' first arrival in the US until their confinement in the camps was essentially characterized by the discriminatory sentiment they encountered. In the receiving society, the government and the majority usually strive to integrate minorities into the established rules and norms of the society, as well as maintain and expand their social merits and privileges. If the majority in the receiving society finds no difference between themselves and immigrants, and if the majority shares a mutual interest with them, the immigrants are easily accepted into the society. This type of integration is often related 
to the interest not only of the receiving society, but also of those who are accepted (Muller, 2001, pp. 17-40).

However, the first generation of Japanese immigrants had a different story and experienced many difficulties. It is impossible to explain these difficulties with only the simple understanding of multiculturalism that insists that they were eventually able to reclaim their identity as Americans because of the success of the compensation movement (Okamoto, 2005, p. 74). Their struggle largely emanated from the "shaking" of their identity, especially from the time of their arrival in the US in 1900 until 1945. Although they are "accepted" in multicultural American society today, it is impossible for them to erase their complicated experiences and memories from that period.

Sakaguchi (2001) contends that the period during which the identity of Japanese immigrants was transformed can be divided into three periods: (1) from the 1900s, when they first migrated, to the 1920s, when they "did not care that they were Japanese"; (2) from the 1920s to the 1930s, when they were "half-Japanese"; and (3) the period after the 1930s, when they had to identify themselves as either Japanese or American. In this way, Japanese immigrants continually sought an identity that could bridge the two conflicting nations for approximately 45 years (Sakaguchi, 2001, pp. 17-42).

The selection of a nation, Japan or the US, that Japanese immigrants in America were forced to identify themselves with successfully led some of them to reside in harmony with fellow Americans, but left others with an unbearable contradiction and unforgettable experiences. This was partly because, regardless of the result of their selection, the structure of the society of Japanese immigrants was profoundly, sometime uncontrollably, influenced by the national interests of the US and Japan, and thus influenced by their diplomatic relations. One of America's true goals was securing its national interests. It might be natural that when a national interest is tied to the loyalty of immigrants, the immigrants are induced to transform their identities into something that confirms the prevailing order of their living environment and demonstrates their loyalty to the receiving country. In reality, an uncountable number of Japanese immigrants followed this path toward acceptance in America (Muller, 2007, pp. 73-82). However, the influence of the diplomatic relationship between Japan and the US became particularly salient for Japanese immigrants when it deteriorated before and during the Second World War. At that time, neither government showed any interest in the immigrants' decisions about the nation to which they demonstrated their loyalty. Even if the immigrants demonstrated their loyalty to Japan, with a firm belief 
that they were Japanese, the Japanese government did not make any real efforts to improve the living conditions of Japanese Americans isolated in the US. Similarly, when they demonstrated their loyalty to America, the US government did not try to respectfully accommodate them or improve their living environment either. Consequently, Japanese immigrants had no choice other than being held in concentration camps from the beginning of the war between Japan and the US (Hayashi, 2004, pp. 76-81).

This analysis of Japanese immigrants' history in the US varies significantly from what has been told in the context of contemporary American multiculturalism. The history of Japanese immigrants in the widely accepted discourse of multiculturalism usually concentrates on their successful identity transformation during the period from their compulsory confinement to the compensation movement, and scarcely mentions the fact that American society during those 45 years was characterized by widespread political, economic, and social oppression of Japanese immigrants, of which the compulsory confinement was just an ultimate consequence (Togami, 1986, p. 319). The mainstream discourse of multiculturalism in the US ignores these historical complexities and only emphasizes the compulsory confinement and victorious compensation campaign by Japanese immigrants after the war, which presumably led them to transform their identities successfully. In a way, multiculturalism only touches upon the history of Japanese immigrants in order to recognize and share their story of loyalty and successive contribution to America.

The reason why American multiculturalism discourses deal with the compulsory confinement and the compensation movement, and recognize the loyalty and contribution of some Japanese immigrants, is to promote the integration of minority ethnic groups in America (Morimo, 1999, pp. 175-180). In other words, the compulsory confinement and compensation movement of the Japanese immigrants are described only in the context of "loyalty" and "contribution." What is missing in this context is the exclusion of those who did not fit the ideal figure of the successful immigrant. Those who have not been described in the history are those who did not demonstrate their loyalty to America, who were consequently excluded from the social structures of both America and Japan, and who continuously experienced the "shaking" of their identities even after the success story of Japanese immigrants prevailed.

\subsection{Narratives of Japanese immigrants}

According to Creswell (2013, p. 13), there are five major research designs that are typically found in a qualitative approach. The first, 
phenomenological research, is a design of inquiry in which the researcher describes the lived experiences of individuals in relation to a phenomenon and as they are described by the participants. This description culminates with a description of the essence of the experiences for several individuals who have all experienced the phenomena (Giorgi, 2009; Moustakas, 1994). The second, grounded theory, is a design of inquiry from sociology in which the researcher derives a general, abstract theory of a process, action, or interaction grounded in the views of participants (Charmaz, 2006; Corbin \& Strauss, 2007). Ethnography, the third type, is a design of inquiry coming from anthropology and sociology in which the researcher studies the shared patterns of behaviors, language, and actions of an intact cultural group in a natural setting over a prolonged period time (Creswell, 2013). The fourth type, case studies, are a design of inquiry found in many fields, especially evaluation, in which the researcher develops an in-depth analysis of a case, often a program, event, or activity, and researchers then collect detailed information using a variety of data collection procedures over a sustained period of time (Stake, 1995; Yin, 2009, 2012). Narrative research, the final design of inquiry, comes from the humanities and features researchers who study the lives of individuals and ask one or more individuals to provide stories about their lives (Riessman, 2008). This information is then often retold and re-storied by the researcher into a narrative chronology. Often, in the end, the narrative combines views from the participant's life with those of the researcher's life in a collaborative narrative (Clandinin \& Connelly, 2000).

In order to research the "shaking" of the identities of Japanese immigrants in this thesis, I conducted oral and written interviews using the methodology of qualitative narrative research with 15 second-generation Japanese Americans in January 2009. ${ }^{2}$ For this narrative approach, the interviewer sought to examine issues related to the oppression of individuals. To study this, stories were collected of individual oppression using a narrative approach (Creswell, 2013). Interviewees were interviewed at some length to determine how they have personally experienced oppression. Interviewees were selected for whom the interview could increase the opportunity "to identify emerging themes" (Erlandson et al., 1993, p. 82) embedded in the interview's context. Along with this research, recorded data were segmented in consideration of every utterance's meaning and subtle nuance. Thus, in the analysis of the data, the information was so dense and rich that the inquiry needed to "winnow" the data (Guest Macqueen \& Namey, 2012), a process of focusing in on some of the data and disregarding other parts of it. Narrative interviews were conducted through 
an unstructured, open-ended format and the interviewer took notes during the interview.

The interviews focused on events related to conscription during the Second World War, which is often described as a constitutive part of the successful history of multiculturalism policy in America. This history regularly treats Japanese immigrants as a positive, and more or less idealized, model of minority groups, with a particular focus on such events as "compulsory confinement" and "conscription of second-generation Japanese Americans," as well as "the compensation movement," which presumably led to the successful transformation of their identities. With these examples, the discourse of multiculturalism frequently associates stories of "the collapse of the identity," "loyalty to America," and "the reconstruction of the identity," in order to present the image of Japanese immigrants as a model of "good citizens" (Japanese American Citizens League, 1996).

As a consequence of the compensation movement, the US government granted prominent recognition to the excellent performance of the 442nd Regimental Combat Team in Europe. ${ }^{3}$ The excellent performance of the combat team was treated as evidence of the Japanese immigrants' loyalty to the US as Americans. Actually, their performance is still widely remembered among Japanese immigrants, and a monument ceremony for the 442nd team in Washington was organized by Japanese immigrant organizations from across the US in 2001 (Befu, 2002, p. 235).

In the context of the mainstream discourse of multiculturalism and the majority of Japanese immigrants, the victory achieved by the compensation movement meant the acceptance of Japanese immigrants. However, it is difficult to tell whether all Japanese immigrants believe that this understanding is reasonable. In fact, Interviewee A, a second-generation Japanese American, has a negative perception of this belief. In addition, Interviewee $B$, another second-generation Japanese American, indicates that the reason why he served in the military did not stem from loyalty to America but from something else. Why do they have a different interpretation of the history of Japanese immigrants? What lies behind their distinctive comprehension of the compensation movement?

Interviewee A, a second-generation Japanese American, was born in Sacramento, California. He was taken to a concentration camp when he was 14 years old. His parents, first-generation Japanese Americans, did not have American citizenship because of the act concerning "aliens ineligible for citizenship." Based in California, he currently visits various schools and other facilities in America to present materials and talk 
about what the compulsory confinement really meant to him. Through these actions, he expresses his identity to the public. The reason why he attracts our attention here is that his identity was not exclusively determined by nationality. He was a model for The No-No Boys, by Teresa Funke (2008). Although this book is a fictional work, it deals with the actual issue of Japanese Americans' struggle for their identity.

He chose to become one of the "No-No Boys," who demonstrated no loyalty to America and refused to serve in the US armed forces. ${ }^{4}$ This choice caused him to be sent to the Tule Lake Camp, which was famous, or infamous, for having the severest surveillance in the US. The Tule Lake camp was a specific facility for those who did not demonstrate their loyalty to America, and for those who were subject to investigation by the FBI. It is said that approximately 18,000 prisoners were held in the Tule Lake Camp, under constant armed surveillance.

Interviewee A talks about the compulsory confinement of Japanese immigrants and their conscription as follows ("[]" signifies information added by the researcher):

In America, many people call where I used to be held a "relocation camp," rather than a "concentration camp." However, based on our understanding, we call it not a relocation camp, but a "jail" or a "concentration camp." We were deprived of our homes, land, stores, jobs, and everything. Nevertheless, it is called a "relocation camp." We feel upset about it. It was a concentration camp without any doubt. Not serving in the military, we had no national identity. We did not know who we were or where we could go. And what was waiting for us, those who did not serve in the military, was detention by the FBI, or repatriation to Japan, or life-long imprisonment at Tule Lake. Meanwhile, I was grateful that I was able to work in the camp as a time-keeper, a cook, a cleaner, and so on. Although the payment was low, it was still good to have a job. Also, I was able to go to school and play sports. That was something to be grateful for, but people around me and I thought that we would be killed if Japan won the war. That kind of anxiety was always with us in the life at the camp. Of course, there was no way of knowing about the progress of the war. We lived our lives at the camp without knowing what was going on. As for the 442nd Team, I, from the perspective of [being a member of] the No-No Boys, have a complicated feeling. Not all the team members who did a good job in the European battlefields demonstrated their loyalty to America. There has always been a political use [of the history of Japanese immigrants]. 
Interviewee A's comments reveal that second-generation Japanese Americans taken to the camps in those days were given only two choices: (1) become a No-No Boy, which would result in either arrest, repatriation to Japan, or life at the Tule Lake Camp, or (2) serve in the military and achieve great performance on the battlefield, which means in this context the 442nd Team.

Based on his own experience, Interviewee A talks about the compulsory confinement and conscription. Interviewee B, another No-No boy, also touches upon the compulsory confinement and conscription. But he goes further to mention the discrimination and exclusion that he experienced after leaving the camp.

Interviewee B was born in Portland, Oregon. He is a second-generation Japanese American, with American citizenship. Since his mother died when he was young, his father made him go back to Japan, where his grandparents lived, but he returned to the US in 1934. Although in the interview he tried not to provide actual details of the compulsory confinement, he explained the exclusion that he had gone through and his agony toward it as follows:

I was born in Portland. But since my mother died while I was still young, my grandparents living in Japan educated me. In 1934, when I was a third-grade student at elementary school, I returned to America. That's why I speak Japanese better than I speak English. Due to the economic downturn [in America] in 1929, I had difficulty finding a job. Since there was terrible economic aggravation and a horrific anti-Japanese attitude at companies run by white Americans, I worked for a Japanese trading company called "Furuya Shoten." The pay was very low. I married my wife before we were sent to a concentration camp. I still feel frustrated that even though we had American citizenship, we were held in the concentration camp. When we were in the camp in Portland, we had our first baby. Since ours was the first baby to be delivered in the camp, this was featured in a newspaper. While I was at the camp, I did not join the military. If I demonstrated my loyalty to America and became conscripted, I could have legally left the camp. But I did not do so. When I left the camp, I was only given a small amount for transportation expenses, enough to go to Ontario. I was completely out of money. The only choices that I had were to work as a farmer or to serve in the army. Every day, I carried my child on my back to school. Actually, after the end of the war, I did serve in the army, because I had no money. The anti-Japanese movement was so severe that I could find no work. In daily life, a shop even refused to sell me an ice cream that my child 
wanted to eat. At a Denny's restaurant, they wouldn't even come to take our order. After leaving the camp, we had no money or job. We just continued to be exposed to the anti-Japanese movement.

Interviewee $\mathrm{B}$ felt resentment that he had been held in a concentration camp, even though he had American citizenship. Also, he stated that he served in the army after the end of the war, but that the choice was not because of loyalty to America but instead the fact that he had no job. Moreover, he emphasized that the discrimination against Japanese immigrants in American society at that time deprived them of opportunities to work.

Interviewee $\mathrm{C}$ was held in the Granada Camp. She describes her experience at the concentration camp and her identity as follows:

I was held in the Granada Camp. I lived in a tiny shack. It was a horrible camp. My parents worked at a vineyard. I had an elder brother. He was drafted as a second-generation Japanese American and went to war in 1944. I spent my years of eighth, ninth, and tenth grades in the camp. Even after leaving the camp, I experienced a lot of difficulties. Since my family had no money, I was taken to my uncle's. I worked at a strawberry farm for low daily wages. My uncle used to tell me that he had actually wanted to go to Tule Lake while he was held in camp. He thought that, if he was taken to Tule Lake, he could leave America for Japan. Meanwhile, even after leaving the camp, I tried not to talk about my experience there. I think that this was because I had something in my mind that could not be classified as American or Japanese. One day, at school, I wrote my American name. It was soon rewritten as my Japanese name by my Japanese teacher. This was an identity problem. I did not understand what my identity was. Japanese Americans like me often use the phrase "facial character." It is something like a surface identity. After the civil rights movement in my living town in 1965 , I thought that my name was called for the first time in my life because that was the first time many minorities started to insist their own ethnic identities. For me, it was the identity of a Japanese American. But later, I noticed that I did not fit in it. The 442nd Team as the symbol of the loyalty of Japanese immigrants is irrelevant to me. To make myself fit in it, I had to throw away something. In my case, it can be said that I've thrown away my Japanese identity.

The "shaking" of her complicated identity is clearly expressed in her national name. She spent her childhood without a clear recognition of whether she was Japanese or American. 
The evidence from these interviews reveals that second-generation Japanese Americans who were held in concentration camps were deprived of their freedom in American society. In discourses regarding multiculturalism, it is said that Japanese Americans have been merged into the majority in America, and that public acceptance by American society relieved the Japanese Americans from having to struggle to establish their identity. However, the descriptions and insistences by each interviewee show that the compulsory confinement did not seem to contribute to their identity formation. Their powerful statements show that they did not assimilate themselves into America and that they have always been residing at the margin of American society. Actually, interviewees talked about their experiences from their own positions. Their descriptions reveal their insistence that they want the world to know about their experiences and they want to tell the world that they have not belonged to a pre-set identity or group.

\subsection{Mainstream discourses of multiculturalism and Japanese immigrants in America}

In order to understand multiculturalism in America, it is necessary to concentrate on the question of the nation state. It can be said that maintaining the identity of Americans is one of the most important issues for maintaining the nation. In America, until the 1970s, 60\% of white residents had British ancestors, and Anglo-conformity was regarded as an ideal of assimilation. In those days, the prevailing socio-cultural understanding was that European culture was central to America. Actually, until the 1960s, Japanese and other Asian immigrants, as well as Mexican immigrants, were not granted rights equal to those of white citizens (Tai, 1999, p. 39).

Homi K. Bhabha analyzes the country's integration process and the issue of ethnic-cultural thought. Emphasizing that identity is never $a$ priori, nor a finished product, Bhabha argues that identity itself is only ever the problematic process of access to an image of totality (Bhabha, 1990, p. 194). In a way, he criticizes the prevailing discourse of diversity that focuses solely on ethnicity. While the integration of ethnic groups into "America" was promoted under the name of multiculturalism, a particular discourse has been accepted as the core narrative of the multicultural environment for American citizens. The implicit assumption held by the majority of the population is that the core of multicultural society needs to be European.

Arthur Schlesinger, Jr. and David A. Hollinger provide typical discussions in this regard. Schlesinger criticized the insistence by African 
Americans on protest against American society. He was absolutely against the protest by African Americans and called their protest self-pity and self-ghettoization as follows:

The ethnicity rage in general and afrocentricity in particular not only divert attention from the real needs but exacerbate the problems. The recent apotheosis of ethnicity, black, brown, red, yellow, white, has revived the dismal prospect that in happy melting-pot days Americans thought the republic was moving safely beyond-that is, a society fragmented into ethnic groups. The cult of ethnicity exaggerates differences, intensifies resentments and antagonisms, drives ever deeper the awful wedges between races and nationalities. The endgame is self-pity and self-ghettoization. (Schlesinger, 1992, p. 102)

He subsequently refers to their protests as separatism. He argues for a core culture in America and suggests that the culture should be based on the superiority of Western culture (Schlesinger, 1992). Similarly, Hollinger strives to promote a discussion that transcends multiculturalism in Postethnic America (Hollinger, 1995). Presenting a negative view of cultural identity generated by ethnic culture, a concept emphasized in the discourse of cultural pluralism and multiculturalism, he expects that such an ethnic element will disappear in terms of political culture. In this context, he criticizes Horace Kallen, who developed and promoted cultural pluralism, and even insists that Kallen was too conscious of his own Jewish ethnicity.

Hollinger regards middle-class people of European ancestry as standard Americans, and defines non-white people as those who stuck to their ethnicity. In the end, his assumption originates in a perception that the center of America was comprised of people with a European tradition.

A truly postethnic America would be one in which the ethno-racial component in identity would loom less large than it now does in politics as well as culture, and in which affiliation by shared descent would be more voluntary than prescribed in every context. Although many middle-class Americans of European descent can now be said to be postethnic in this sense, the United States as a whole is a long way from achieving this ideal. This ideal for the American civic community is, indeed, just that - an ideal, embodying the hope that the United States can be more than a site for a variety of diasporas and of projects in colonization and conquest. (Hollinger, 1995, p. 129) 
He argues that non-white people were ethnic groups sticking to their ethnicity. He continues by suggesting that non-whites do not understand the ideal of the American civic community, of which "individuality" is the indispensable basis, but stuck to their race and ethnicity and ultimately weaken the unitary state of culture. Ultimately, the reason why he tries to transcend multiculturalism is that he thinks the insistence of minority ethnic groups in America would disrupt the superiority of the whites (Hollinger, 1995).

In these discussions, multiculturalism is reduced to "the Politics of Recognition" (Taylor, 1994), which is often criticized for using the concept of diversity to protect the narrator's own culture. Using the phrase "the Politics of Recognition," Charles Taylor contends that the contemporary demand for recognition by minorities has been refused. He insists that in the politics of recognition, the demand for equal citizenship and the uniqueness of each individual must be recognized (Taylor, 1994). However, the problem for multiculturalism is that, under the name of the politics of recognition, there is only one-way recognition of "minority cultures" by the "mainstream culture." Not discussing the question of subjectivity, that is, the question of who has the right to "recognize," overlooks the power relations of narration involved in the case of Japanese immigrants in the context of multiculturalism.

Where cultural differences are observed, multiculturalism supposedly recognizes each different culture with the word "diversity," Bhabha argues that multiculturalism was an effort to control a dynamic process of cultural differences (Bhabha, 1990, p. 209). He contends that both cultural pluralism and multiculturalism regularly function to control cultural differences. The ethical recognition by discourses of multiculturalism deadens the floating and hybrid aspects of minority cultures, and makes the minority cultures named and controlled by the dominant multiculturalism through an essentialist understanding of culture. In the case of Japanese immigrants, no history has been provided in the multicultural education regarding those who did not demonstrate their loyalty to America. Those who have not been described in the discourse of multiculturalism are deprived of the words to explain themselves, and are thus often silenced. Bhabha (1994) analyzes this process as the containment of cultural difference.

In discussions of multiculturalism in American society, Ronald Takaki (2008) touches upon the "cultures recognized." Takaki, a secondgeneration Japanese American intellectual, emphasizes that American history has been very fragmentary and America has been formed by mutual interactions among a wide variety of ethnic groups. With this 
emphasis, he strives to draw a complicated portrait of America. Stating that all groups contributed to the establishment of America, he aims to redefine American history from multiple perspectives by describing the experiences of each group (Takaki, 2008). The multiculturalism advocated by Takaki can apparently be regarded as multiculturalism because of the diversity among the minority viewpoints. In fact, he insists "we originally came from many different shores, and our diversity has been at the center of the making of America" (Takaki, 2008, p. 438). By indicating this diversity, he seeks to establish a shared past for America. By describing history from multiple perspectives, he attempts to create a unified America with assumed diversity, rather than an America constituted by only one specific group.

However, those who continue to be marginalized in the discourse of multicultural America, such as the "No-No Boys," are under continuous pressure to be incorporated into the pre-given American social structure, even while their identities remain marginalized. In short, the problem here is that the existence of those who have been unremittingly pressured by the discourse of multiculturalism, and tried to escape from it, remains silenced and marginalized. The discussion by Takaki is a typical example of the recognition of Asian Americans in the prevailing context of multiculturalism. It functions to promote social integration and conceal the structure of control by the majority, and has enabled the containment of protest movements against the alleged tolerance of America.

If the main function of contemporary multiculturalism is to ceaselessly control minorities, this suggests an imperialist character. In fact, Edward Said frequently referred to the US as an imperialist country (Said, 1993). Has multiculturalism in America been critical of the nation's culture of imperialism? While strengthening national identity, it seems that a multiculturalism based on cultural control, with the veil of tolerance, has been exempt from self-criticism and selfdenial. Likewise, not many Japanese immigrants in the US have had a point of view that would generate criticism of the nation. As explained above, while criticizing the mainstream, Japanese immigrants have not sufficiently criticized the essentialist understanding of culture. In a word, the mainstream multiculturalist discourse in the US has continuously been producing the story of "what it is to be an American" and has constantly depicted the "characteristics of the good Japanese Americans" for Japanese immigrants. This results in the production and isolation of those who have neither "characteristics of Americans" nor "characteristics of the Japanese." 
In reality, history textbooks have incessantly produced such "other people" and used them to spread the discourse of a multicultural America. One history textbook, for instance, told the story that some California residents began to be concerned about the increasing number of Japanese immigrants in their state, and that Japanese immigrants worked for very low wages, depriving native-born non-Japanese American workers of their jobs (Brown, Helgeson \& George, 1964). While emphasizing that Japanese Americans were industrious workers, the textbook ultimately categorized Japanese immigrants as "other people" who caused a negative impact on American society. The textbook tells us about the different perceptions of work held by whites and Japanese Americans. This difference in work ethic is entwined with racial differences and culturally essentialized. In this way, the textbook implants the essentialist idea of ethnicity, on the basis of a comparison between "native-born Americans" and "Japanese immigrants," in the minds of the readers.

Another interesting example is a story described in a textbook about Japanese Americans along the Pacific coast who were forced to leave their homes and were gathered in camps administered by the army following the attack on Pearl Harbor (Bragdon \& McCutchen, 1964). The textbook refers to this violation of compulsory confinement as "the sole significant event." However, the description of the confinement is problematic, because the expression "sole important event" is not correct. This expression conceals the history of compulsory confinement of German Americans and Italian Americans during the same period. Moreover, the textbook implies that the cause of this compulsory confinement was mainly Japan's attack on Pearl Harbor, and this depiction suggests that compulsory confinement would not have been carried out if there was no attack. In other words, the confinement was because of Japan's wrongdoing, and the US's decision on the confinement was inevitable. However, the textbook does not refer at all to the traditional historical aspect described by Japanese immigrants, who say that the compulsory confinement was a mere extension of the exclusion of and discrimination against Japanese immigrants (Okamoto, 2005).

As suggested above, multiculturalism, which was originally supposed to be related to the concept of "diversity," has come to function as an apparatus for controlling minority identity, while still being intertwined with the concept of "integration." The result was the reproduction of a strong American identity. Avery F. Gordon and Christopher Newfield described this as "the control of diversity," and insists that multiculturalism does not question the imbalance generated by race, class, and gender differences in the context of the multicultural situation and instead 
conceals this problem while providing an effective control (Gordon \& Newfield, 1996).

\subsection{Conclusion}

Through discussing problems regarding Japanese immigrants in the context of multiculturalism, this chapter has striven to indicate the difference between those who were assimilated in multiculturalism and those who were not. In past studies, Japanese immigrants have been understood from a certain fixed perspective, which is a multiculturalism of essentialization and isolation. This results in promoting the isolation of "others" while accepting them with its supposed tolerance. However, this process inevitably produces another form of "others" who appear within the community of the pre-given "others." As the antithesis to such an understanding, this chapter aimed to emphasize the differences among Japanese immigrants. The statements by each interviewee describe the "shaking" of their identity woven through their experiences. In order to promote discussions of multiculturalism in the circumstances surrounding immigrants, it is necessary to pay careful attention to ensure that the discussions are not oriented towards the integration of difference but rather toward the diversification of identities.

\section{Notes}

1. Since the process of the historical development and transformation of multiculturalism and multicultural education is more deeply discussed in the third section, I focus here on how Japanese immigrants have been described in the current discourse of multiculturalism.

2. The field research for this thesis was supported by the Graduate Program of Asian and African Studies of Ryukoku University. Further, direct contact and oral or written interviews with second-generation Japanese Americans became possible through the cooperation of Ronald Nakasone (Stanford University).

3. In 1942, General Emmons, in Hawaii, formed a battalion of Japanese Americans-the 100th Battalion. The 100th was called the "Purple Heart Battalion." In June 1943, the 100th Battalion merged with the newly arrived 442nd Regimental Combat Team, composed of Japanese Americans from Hawaii as well as from the concentration camps on the mainland (Takaki, 2008, pp. 348-349).

4. In 1943, the War Relocation Authority administered a loyalty questionnaire to all male and female internees 17 years and older. The crucial questions were No. 27 and No. 28, as follows (Tule Lake Committee, 2000, p. 8):

No. 27: Are you willing to serve in the armed forces of the United States on combat duty, wherever ordered? 
No. 28: Will you swear unqualified allegiance to the United States of America and faithfully defend the United States from any or all attack by foreign or domestic forces and forswear any form of allegiance or obedience to the Japanese emperor, to any other foreign government, power or organization?

\section{References}

Befu, H. (2002). Nikkei americajin no ayumi to genzai [Steps by Japanese Americans and today]. Tokyo: Jinbun Shoin.

Bhabha, H. K. (1990). The third space. In J. Rutherford (Ed.), Identity: Community, culture, difference (pp. 207-221). London: Lawrence and Wishart.

Bhabha, H. K. (1994). The location of culture. London: Routledge.

Bragdon, H. W. \& McCutchen, S. P. (1964). History of a free people. New York: The Macmillan.

Brown, R. C., Helgeson, C. A., \& George, L. H. (1964). The United States of America: A history for young citizens. Morristown, NJ: Silver Burdett.

Charmaz, K. (2006). Constructing grounded theory. Thousand Oaks, CA: Sage.

Clandinin, D. J. \& Connely, F. M. (2000). Narrative inquiry: Experience and story in qualitative research. San Francisco: Jossey-Bass.

Corbin, J. M. \& Strauss, A. C. (2007). Basics of qualitative research: Techniques and procedures for developing grounded theory (3rd edn). Thousand Oaks, CA: Sage.

Creswell, J. W. (2013). Research design: Qualitative, quantitative, and mixed methods approaches (4th edn). Thousand Oaks, CA: Sage.

Erlandson, D. A., Harris, E. L., Skipper, B. L., \& Allen S. D. (1993). Doing naturalistic inquiry: A guide to methods. Newbury Park, CA: Sage.

Funke, T. (2008). The no-no boys. Fort Collins, CO: Victory House Press.

Giorgi, A. (2009). The descriptive phenomenological method in psychology: A modified Husserlian approach. Pittsburgh, PA: Duquesne University Press.

Gordon, A. F. \& Newfield, C. (Eds) (1996). Mapping multiculturalism. Minneapolis: University of Minnesota Press.

Grant, C. A. \& Sleeter, C. E. (2009). Turning on learning: Five approaches for multicultural teaching plans for race, class, gender, and disability (5th edn). New York: Wiley.

Guest, G., MacQueen, K. M., \& Namey, E. E. (2012). Applied thematic analysis. Thousand Oaks, CA: Sage.

Hayashi, B. M. (2004). Democratizing the enemy: The Japanese American internment. Princeton, NJ: Princeton University Press.

Hollinger, D. A. (1995). Postethnic America: Beyond multiculturalism. New York: Basicbooks.

Inoue, T. (1999). Tabunkashugi no seiji tetsugaku: Bunkaseiji no toriade [Political philosophy of multiculturalism: Triade of cultural politics] In D. Yui, \& Y. Endo (Eds), Tabunkashugi no america: Yuragu nashonaru aidentiti [The US of multiculturalism: Shaken national identity] (pp. 87-114). Tokyo: Tokyo Daigaku Shuppankai.

Japanese American Citizens League, National Education Committee. (1996). A lesson in American history: The Japanese American experiences, curriculum and resources guide. San Francisco: JACL.

Morimo, T. (1999). America no rekishikyouiku niokeru kokumintougou to tabunkashugi [Multiculturalism and integration of American history 
education]. In D. Yui, \& Y. Endo (Eds), Tabunkashugi no america: Yuragu nashonaru aidentiti [The US of multiculturalism: Shaken national identity] (pp. 165-186). Tokyo: Tokyo Daigaku Shuppankai.

Moustakas, C. (1994). Phenomenological research methods. Thousand Oaks, CA: Sage.

Muller, E. L. (2001). Free to die for their country: The story of the Japanese American draft resisters in World War II. Chicago: The University of Chicago Press.

Muller, E. L. (2007). American inquisition: The hunt for Japanese American disloyalty in World War II. Chapel Hill, NC: The University of North Carolina Press.

Okamoto, T. (2005). Rekishi kyoukasho ni miru america [The America found in history textbooks]. Tokyo: Gakubunsha.

Petersen, W. (1971). Japanese Americans: Oppression and success. New York: Random House.

Riessman, C. K. (2008). Narrative methods for the human sciences. Thousand Oaks, CA: Sage.

Said, E. W. (1993). Culture and imperialism. New York: Alfred A. Knopf.

Sakaguchi, M. (2001). Nihonjin america iminshi [History of Japanese American immigrants]. Tokyo: Fuji Shuppan.

Schlesinger Jr., A. M. (1992). The disuniting of America: Reflections on the multicultural society. New York: Norton.

Stake, R. E. (1995). The art of case study research. Thousand Oaks, CA: Sage.

Tai, E. (1999). Tabunkashugi to diaspora [Multiculturalism and diaspora]. Tokyo: Akashi Shoten.

Takaki, R. (2008). A different mirror: A history of multicultural America. New York: Little Brown and Company.

Taylor, C. (1994). The politics of recognition. In A. Gutmann (Ed.), Multiculturalism: Examining the politics of recognition (pp. 25-73). Princeton, NJ: Princeton University Press.

Togami, S. (1986). Japanese American: Ijyuu kara jiritu eno ayumi [Japanese American: Steps of self-reliance from immigration]. Kyoto: Minerva Shobo.

Tule Lake Committee. (2000). Second kinenhi: Reflections on Tule Lake. San Francisco: Tule Lake Committee.

Yin, R. K. (2009). Case study research: Design and methods (4th edn). Thousand Oaks, CA: Sage.

Yin, R. K. (2012). Applications of case study research (3rd edn). Thousand Oaks, CA: Sage.

Yoneyama, R. (2003). Bouryoku, sensou, ridoresu: Tabunkashugi no politics [Violence, war, and redress: The politics of multiculturalism]. Tokyo: Iwanami Shoten.

Yui, D. \& Endo, Y. (Eds) (1999). Tabunkashugi no america: Yuragu nashonaru aidentiti [The US of multiculturalism: Shaken national identity]. Tokyo: Tokyo Daigaku Shuppankai.

Except where otherwise noted, this work is licensed under a Creative Commons Attribution 3.0 Unported License. To view a copy of this license, visit http://creativecommons.org/licenses/by/3.0/ 